\title{
Evaluation of the reporting quality of clinical practice guidelines on lung cancer using the RIGHT checklist
}

\author{
Yongjie Yang ${ }^{1,2 \#}$, Jingli Lu ${ }^{1,2 \#}$, Yanfang $\mathrm{Ma}^{3}$, Chen $\mathrm{Xi}^{1,2}$, Jian Kang ${ }^{1,2}$, Qiwen Zhang ${ }^{1,2}$, Xuedong Jia ${ }^{1,2}$, \\ Kefeng Liu ${ }^{1,2}$, Shuzhang Du ${ }^{1,2}$, Florian Kocher ${ }^{4}$, Andreas Seeber ${ }^{4}$, Cesare Gridelli ${ }^{5}$, Mariano Provencio ${ }^{6}$, \\ Nobuhiko Seki ${ }^{7}$, Yusuke Tomita ${ }^{8}$, Xiaojian Zhang ${ }^{1,2}$
}

${ }^{1}$ Department of Pharmacy, the First Affiliated Hospital of Zhengzhou University, Zhengzhou, China; ${ }^{2}$ Henan Key Laboratory of Precision Clinical Pharmacy, Zhengzhou University, Zhengzhou, China; ${ }^{3}$ School of Chinese Medicine of Hong Kong Baptist University, Hong Kong, China; ${ }^{4}$ Department of Hematology and Oncology, Comprehensive Cancer Center Innsbruck, Medical University Innsbruck, Innsbruck, Austria; ${ }^{5}$ A.O.R.N. San Giuseppe Moscati, Contrada Amoretta, Avellino, AV, Italy; ${ }^{6}$ Medical Oncology Department, Hospital Universitario Puerta de Hierro Majadahonda, Madrid, Spain; ${ }^{7}$ Division of Medical Oncology, Department of Internal Medicine, Teikyo University School of Medicine, Tokyo, Japan; ${ }^{8}$ Department of Respiratory Medicine, Graduate School of Medical Sciences, Kumamoto University, Kumamoto, Japan

Contributions: (I) Conception and design: X Zhang, Y Yang; (II) Administrative support: J Kang, S Du; (III) Provision of study materials: C Xi, X Jia, K Liu; (IV) Collection and assembly of data: Y Ma, J Lu, Q Zhang; (V) Data analysis and interpretation: J Lu, F Kocher, A Seeber, C Gridelli, M Provencio, N Seki, Y Tomita; (VI) Manuscript writing: All authors; (VII) Final approval of manuscript: All authors.

\#These authors contributed equally to this work.

Correspondence to: Xiaojian Zhang. Department of Pharmacy, The First Affiliated Hospital of Zhengzhou University, No.1 Jianshe East Road, Zhengzhou, China. Email: fcczhangxj@zzu.edu.cn.

Background: In recent years, the number of clinical practice guidelines (CPGs) for lung cancer has increased, but the quality of these guidelines has not been systematically assessed so far. Our aim was to assess the reporting quality of CPGs on lung cancer published since 2018 using the International Reporting Items for Practice Guidelines in Health Care (RIGHT) instrument.

Methods: We systematically searched the major electronic literature databases, guideline databases and medical society websites from January 2018 to November 2020 to identify all CPGs for small cell and nonsmall cell lung cancer (NSCLC). The search and extraction were completed using standardized forms. The quality of included guidelines was evaluated using the RIGHT statement. We present the results descriptively, including a stratification by selected determinants.

Results: A total of 49 CPGs were included. The mean proportion across the guidelines of the 22 items of the RIGHT checklist that were appropriately reported was $57.9 \%$. The items most common to be poorly reported were quality assurance (item 17) and description of the role of funders (item 18b), both of which were reported in only one guideline. The proportions of items within each of the seven domains of the RIGHT checklist that were correctly reported were Basic information $75.9 \%$; background $83.2 \%$; evidence $44.5 \%$; recommendations $55.4 \%$; review and quality assurance $12.2 \%$; funding and declaration and management of interests $42.9 \%$; and other information $38.1 \%$. The reporting quality of guidelines did not differ between publication years. CPGs published in journals with impact factor $>30$ tended to be best reported.

Conclusions: Our results revealed that reporting in CPGs for lung cancer is suboptimal. Particularly the declaration of funding and quality assurance are poorly reported in recent CPGs on lung cancer.

Keywords: Lung cancer; International Reporting Items for Practice Guidelines in Health Care checklist (RIGHT checklist); reporting quality; clinical practice guidelines

Submitted Mar 05, 2021. Accepted for publication Jun 11, 2021.

doi: $10.21037 /$ tlcr-21-405

View this article at: https://dx.doi.org/10.21037/tlcr-21-405 


\section{Introduction}

Lung cancer is the leading cause of cancer-related deaths worldwide (1). In 2018, about 2.1 million new diagnoses and 1.8 million deaths related to lung cancer were estimated globally (2). The most common types of lung cancer are non-small cell lung cancer (NSCLC) and small-cell lung cancer (SCLC) accounting for $76 \%$ and $13 \%$ of all cases of lung cancer, respectively (3). Data from the Surveillance, Epidemiology, and End Results (SEER) program demonstrates that population-level mortality from NSCLC fell in recent years, and this decrease was associated with the use of targeted therapies (3). The clinical outcomes of targeted therapies are superior to those of traditional cytotoxic chemotherapy in patients with oncogenic-driven NSCLC (4). Next to targeted therapies, only recently immune checkpoint inhibitors have improved the outcomes of both NSCLC and SCLC, dramatically (5). The increasing complexity of molecular pathology and the growing number of new therapeutic agents has brought the management of lung cancer patients into an era of precision medicine. Thus, it is important to accurately use the latest available evidence to make best clinical decisions for these patients.

Clinical practice guidelines (CPGs) are collections of statements that include recommendations intended to optimize patient care. These statements are informed by a systematic review of evidence and an assessment of the benefits and costs of alternative care options. The process of developing a CPG is time-consuming and costly, but CPGs may, once published and implemented, have a tremendous impact on clinical decisions and patients' lives. Many evidence-based guidelines have been developed for the management of lung cancer. Usually, guidelines should be updated are every three to five years $(6,7)$, however, due to rapid diagnostic and treatment changes, oncology guidelines should be updated annually (8). Since the number of CPGs has increased rapidly, growing concern about the variation in their quality becomes evident. The reporting quality is an important factor influencing the quality of guidelines, contributing to the way the recommendations are implemented. Thus, standardized and formal methods are needed to assess the reporting quality of CPGs.

For this reason, the International Reporting Items for Practice Guidelines in Health Care (RIGHT) instrument was developed in 2016 (9). The RIGHT checklist includes seven domains with 22 items to facilitate complete and transparent reporting, and help developers prepare the guidelines. Given the rapid accumulation of new evidence in therapeutic strategies, adherence to these checklists is particularly relevant for guidelines evaluating lung cancer. In this study, we evaluated the reporting quality of guidelines for lung cancer patients, and investigated how the quality in guideline reporting varies across time and by selected characteristics.

\section{Methods}

\section{Literature search}

We systematically searched Medline (via PubMed), Chinese Biomedical Literature Database (CBM), Wan Fang Database and Chinese National Knowledge Infrastructure (CNKI) to identify CPGs for lung cancer from January 1, 2018 to November 15, 2020. The search strategy combined the following terms: "lung neoplasms", "lung cancer", "practice guideline", "guidance", and "recommendation". Language was restricted to Chinese and English. We also searched the websites of the National Institute for Health and Care Excellence (NICE, https://www.nice.org.uk/), National Comprehensive Cancer Network (NCCN, https:// www.nccn.org/), World Health Organization guidelines (WHO, https://www.who.int/publications/guidelines/year/ en/), Scottish Intercollegiate Guidelines Network (SIGN, https://www.sign.ac.uk/our-guidelines/) and Guidelines International Network (GIN, https://guidelines.ebmportal. com/), as well as Google Scholar as a supplemental source. Additional details of our search strategy are provided in Appendix 1.

\section{Inclusion criteria and exclusion criteria}

CPGs were considered eligible if they met the following criteria: (I) the CPG was published in English or Chinese; (II) the focus of the CPG was screening, testing, diagnosis, treatment or management of lung cancer; (III) full-text of the CPG was available and accessible; and (IV) the CPG was the latest version. Interpretations and summaries of guidelines, and draft guidelines not yet formally published were excluded.

\section{Screening}

Two authors (YF Ma and QW Zhang) independently identified eligible CPGs and retrieved the full texts and any related supplementary materials (Appendix 1). Discrepancies were adjudicated by a third reviewer $(\mathrm{C} \mathrm{Xi})$. 


\section{Data extraction of guidelines}

Data were extracted independently by two authors (XD Jia and KF Liu) using a standardized electronic form. Disagreements were settled by consultation. The data extracted from each CPG included the name of the first author, publication year, publication language, region/ country where the CPG was developed, developers (institution or working group), format of publication (peerreviewed journal, or website only), impact factor (IF) of the journal according to SCI (Science Citation Index), and the scope/purpose and target population of CPGs.

\section{Reporting quality assessment using the RIGHT checklist}

The reporting quality of CPGs was evaluated using the RIGHT instrument, which includes 22 key items categorized into seven domains. Some key items are further divided into two or three sub-items, reaching a total of 35 items. The seven domains are: basic information (6 items), background (8 items), evidence (5 items), recommendations (7 items), review and quality assurance (2 items), funding and conflicts of interest statements and management (4 items), and other information (3 items). We rated each item as "reported" if the relevant information was fully presented, "not reported" if some relevant information was lacking, or "not applicable" if the item was not applicable for evaluating the specific guidelines, based on the protocol of RIGHT instrument. The authors who performed the assessment were trained by a member of RIGHT checklist working group (YF Ma). Two investigators independently evaluated the reporting quality according to the RIGHT statement (JL Lu and YJ Yang). Disagreements between reviewers were resolved through consensus or consulting an independent expert adjudicator (J Kang).

\section{Statistical analysis}

We calculated the reporting rates of the RIGHT checklist items for all 35 items separately (percentage of all CPGs that reported the item), for each domain (mean over the reporting rates of all items of each particular domain across all CPGs), and overall (mean over all items and CPGs). All 35 items were weighted equally in the calculation of the domain and overall scores, and those assigned as "not applicable" were included in the denominator. We also present results stratified by the year of publication, language, region/country of origin, and format of publication (peer-reviewed journals categorized by impact factor, or website only).

\section{Results \\ Identification of specific guidelines}

The search yielded a total of 668 potentially relevant records (Figure 1). Sixty-five records were removed as duplicates, and 536 records were excluded after screening titles and abstracts. After an extensive review of the full texts of the remaining 67 records, a total of 49 CPGs were deemed eligible and included in the appraisal process.

\section{Characteristics of selected guidelines}

The characteristics of the CPGs are summarized in Table 1. Seven CPGs were established for SCLC (10-16), 20 for NSCLC (17-36), and 22 for lung cancer regardless of histological subtype (37-58). The number of published CPGs increased every year, with a total of 22 CPGs published in 2020. Eight guidelines (16.3\%) focused on screening, 6 guidelines (12.2\%) on testing, 30 guidelines $(61.2 \%)$ on diagnosis and treatment, and 5 guidelines $(10.2 \%)$ on the management of lung cancer. Forty-two CPGs were developed by medical specialty societies, and seven were developed by guideline working groups not associated with any medical society. Medical specialty societies from the United States were the most common guideline developers, accounting for 11 (22.4\%) of CPGs. Eight CPGs were developed in China, five in Spain, four in Italy, one in Brazil, one in Canada, one in Japan, one in Saudi Arabia, one in India, one in the UK, five by European multinational collaborations, four by multinational collaborations from other regions, and six by international organizations. Forty-five of the 49 CPGs were published in journals, one on the NICE website only, one on the CSCO website only, and two on the NCCN website only. Guidelines developed in the US tended to be published in journal with higher impact factor (IF), and the three that were published in the highest-impact journal (IF >30) were all developed or endorsed by the American Society of Clinical Oncology (ASCO). Details on the study characteristics are shown in Table S1.

\section{Overall analysis of reporting quality}

The reporting rates for the seven domains ranged from $12.2 \%$ to $83.2 \%$. The "basic information" and "background" domains had the highest reporting proportions $(75.9 \%$ and 


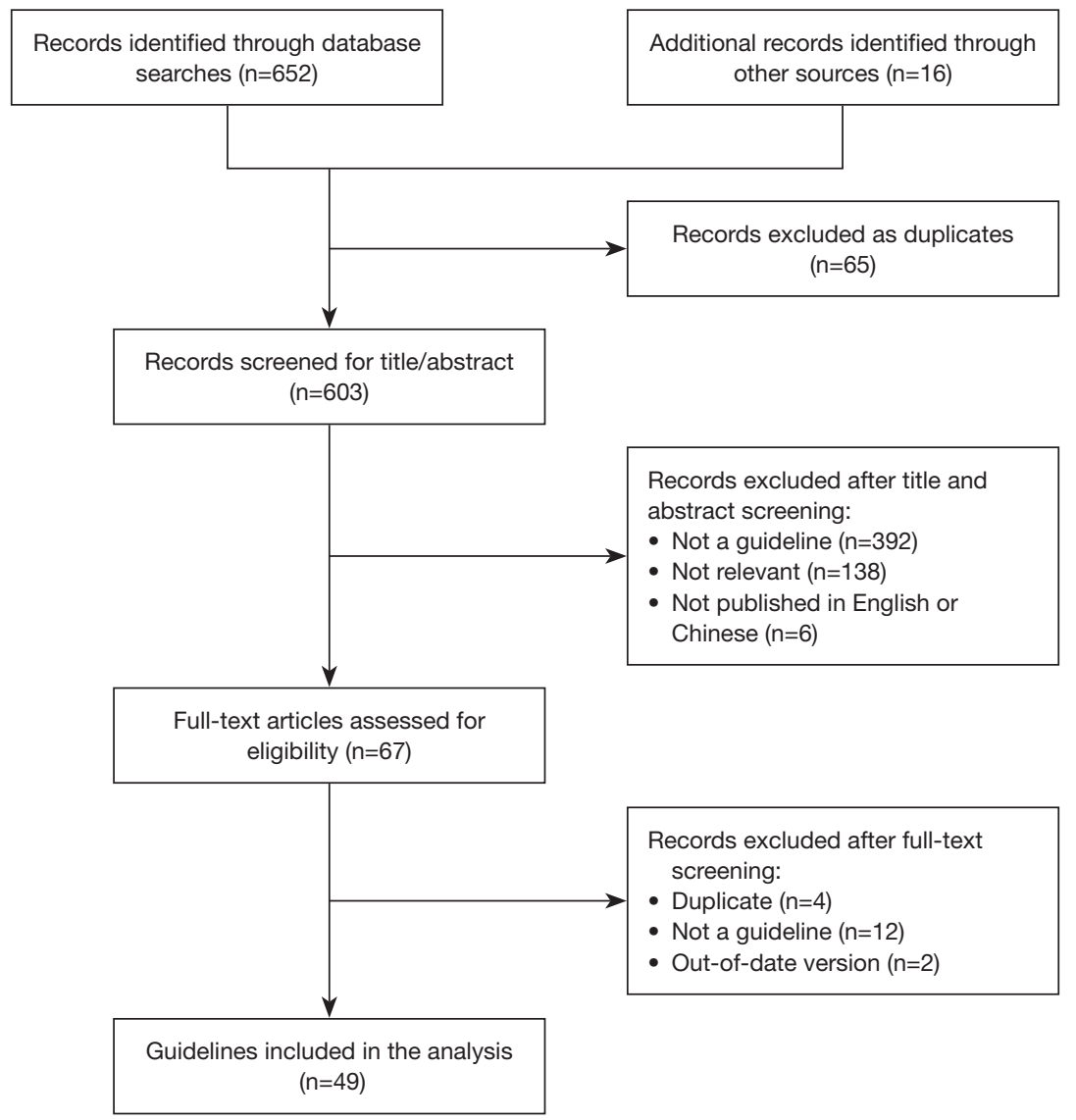

Figure 1 Flow chart of the literature review.

$83.2 \%$, respectively). The "recommendations" domain also had a reporting rate above $50 \%$. The "review and quality assurance" domain had the lowest reporting rate (12.2\%). The reporting rates for the remaining domains were $44.5 \%$ for "evidence", $42.9 \%$ for "funding and declaration and management interests", and 38.1\% for "other information" (Figure 2).

The mean overall reporting proportion over all 35 items was $57.9 \%$. The number of reported items ranged from 12 (38.7\%) to $31(92.1 \%)$ across the guidelines. All guidelines $(100 \%)$ adhered to items $3,7 \mathrm{a}$ and $13 \mathrm{a}$, and items $1 \mathrm{a}, 1 \mathrm{c}, 6$, $7 \mathrm{~b}, 9 \mathrm{~b}$ and $13 \mathrm{~b}$ were also reported by more than $90 \%$ of the guidelines. Items 17 and $18 \mathrm{~b}$ had the poorest reporting rate, both being described in only one CPG (Table 2).

\section{Stratified analyses of reporting quality}

The overall mean reporting proportions by year of publication were $58.0 \%$ in $2018,58.6 \%$ in 2019 , and $57.3 \%$ in 2020 . The quality of reporting was best in guidelines published in journals with IF $>30$ (overall reporting rate $78.1 \%$ ); those published in Chinese-language journals without IF had the lowest overall reporting rate $(51.9 \%)$. The overall reporting proportion in the English-language guidelines was $59.0 \%$, and in Chineselanguage guidelines $51.0 \%$. Guidelines from multinational regional collaborations (except Europe), USA and Italy had the highest reporting rates $(65.7 \%, 63.3 \%$ and $63.6 \%$, respectively), while the guidelines by China and European multinational organizations had the lowest rate $(49.6 \%$ and $49.7 \%$, respectively) (Figure 3).

\section{Discussion}

In this appraisal of 49 CPGs for lung cancer using the RIGHT checklist, the overall reporting rate reached $57 \%$, with 18 CPGs having a rate higher than $60 \%$. The guidelines with high reporting rates had some common features: they were often published in journals with high IF, and they were developed by medical specialty societies who 
Table 1 Characteristics of the eligible CPGs

\begin{tabular}{|c|c|}
\hline Study characteristics & CPGs, n (\%) \\
\hline Total & $49(100)$ \\
\hline \multicolumn{2}{|l|}{ Histological classification } \\
\hline Lung cancer & $22(44.9)$ \\
\hline Non-small cell lung cancer & $20(40.8)$ \\
\hline Small cell lung cancer & 7 (14.3) \\
\hline \multicolumn{2}{|l|}{ Scope and purpose } \\
\hline Screening & $8(16.3)$ \\
\hline Diagnosis and treatment & $30(61.2)$ \\
\hline Testing & $6(12.2)$ \\
\hline Management & $5(10.2)$ \\
\hline \multicolumn{2}{|l|}{ Organization of guidelines } \\
\hline Association/society & $42(85.7)$ \\
\hline Development working group & $7(14.3)$ \\
\hline \multicolumn{2}{|l|}{ Language } \\
\hline English & $42(85.7)$ \\
\hline Chinese & $7(14.3)$ \\
\hline \multicolumn{2}{|l|}{ Region/country of origin } \\
\hline Global $^{+}$ & $6(12.2)$ \\
\hline Multinational regional (Europe) & $5(10.2)$ \\
\hline Multinational regional (other regions)* & $4(8.2)$ \\
\hline USA & $11(22.4)$ \\
\hline China & $8(16.3)$ \\
\hline Spain & $5(10.2)$ \\
\hline Italy & $4(8.2)$ \\
\hline Others ${ }^{\#}$ & $6(12.2)$ \\
\hline \multicolumn{2}{|l|}{ Reporting year } \\
\hline 2018 & $10(20.4)$ \\
\hline 2019 & $17(34.7)$ \\
\hline 2020 & $22(44.9)$ \\
\hline \multicolumn{2}{|l|}{ Journal's IF } \\
\hline Chinese-language journals without IF & $6(12.2)$ \\
\hline English-language journals without IF & $4(8.2)$ \\
\hline IF 0-5 & $16(32.6)$ \\
\hline IF 5-10 & $9(18.4)$ \\
\hline IF 10-30 & $7(14.3)$ \\
\hline IF $>30$ & $3(6.1)$ \\
\hline Websites only & $4(8.2)$ \\
\hline
\end{tabular}

${ }^{+}$, International organizations; *, North America, Pan-Asia, Southern Africa; ", UK, Canada, Japan, Brazil, Saudi Arabia, India. CPGs, clinical practice guidelines; IF, impact factor. are likely to have internal guidelines for systematic, explicit and rigorous guideline development methodology, such as the ASCO Guideline Program (59). Because the RIGHT checklist only addresses reporting of CPGs, assessing the quality of published CPGs was beyond the scope of this analysis. A high reporting rate indicates good reporting quality, but does not imply that the recommendations are in line with the best practice for disease management.

The items in the "basic information" and "background" domains were well reported in the CPGs included in our analysis. Previous studies assessing other diseases have also found high reporting rates in these two domains $(60,61)$. However, some improvements in these areas are still needed. Item $1 \mathrm{~b}$ [describe the year of publication (in the title)] had the lowest reporting rate within these two domains. Even many guidelines that otherwise adhered well to the RIGHT checklist, such as some guidelines developed by ASCO, ASTRO and CHEST, did not adhere to this item $(14,21,58)$. Interestingly, showing the publication year within the title is important for readers to see immediately if the recommendations are up to date. In addition, less than half of the CPGs provided a summary of the recommendations (item 2), and almost $60 \%$ did not describe the selection process, roles and responsibility of the contributors (item 9a).

The "recommendations" domain achieved a reporting rate of $55.4 \%$, which is higher than in CPGs for some other diseases $(60,61)$. However, the items that are associated with explaining the recommendation and describing the decision process remained poorly reported. The aim of all lung cancer CPGs is to synthesize the best expert recommendations, but the applicability of the recommendations is also influenced by many factors, such as racial/ethnic and age disparities, geographic location, and the type of healthcare facility (62-65). Treatment costs also need to be taken into consideration (66). CPG developers should strive to account for these health disparities in order to provide the highest level of cancer care; therefore, this is particularly important for reporting these recommendations.

With very few exceptions, the guidelines performed poorly in the domain "Review and quality assurance", with a reporting proportion of less than $20 \%$. In particular, only one CPG indicated whether the guideline was subject to a quality assurance process (58). Although 11 guidelines reported limited information about an external review, the details of how the review was executed and how the feedback from the review was utilized were lacking. The reason for poor reporting in this domain is difficult to ascertain. One 


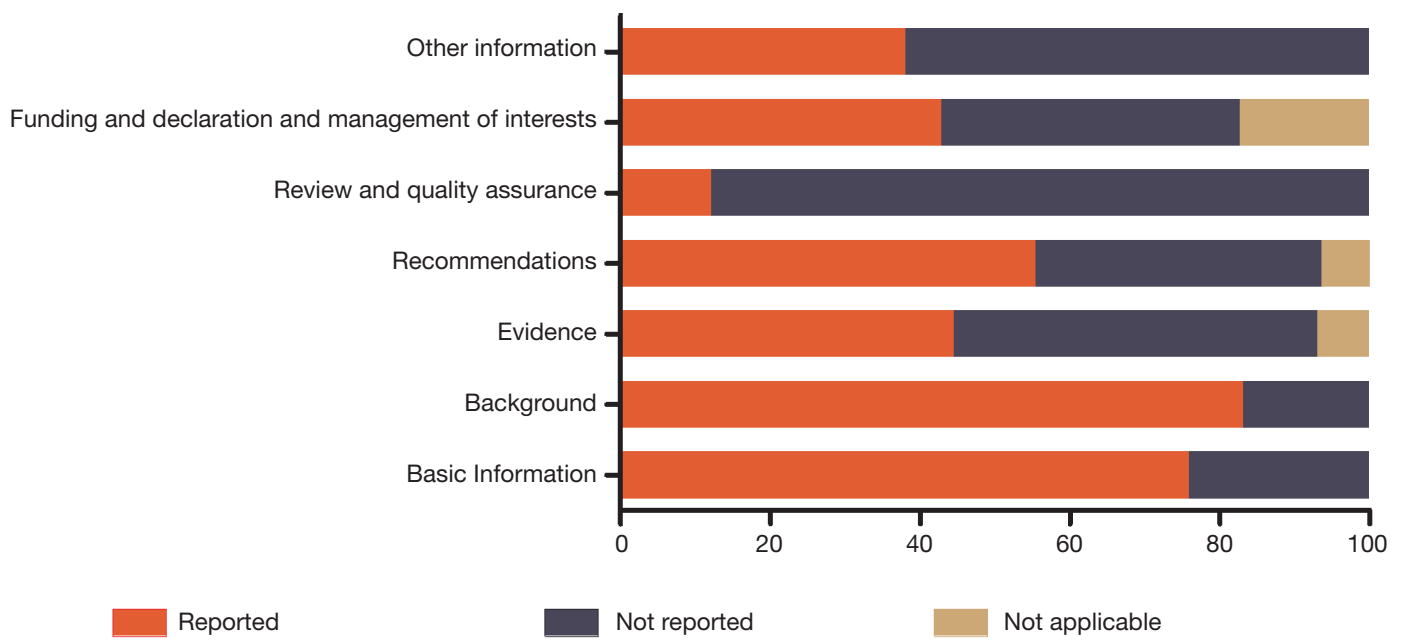

Figure 2 The reporting rates of the RIGHT checklist domains in the included CPGs. RIGHT, International Reporting Items for Practice Guidelines in Health Care; CPGs, clinical practice guidelines.

possible reason may result from the assumption that the readers may consider the review process less important than the adequacy of clinical content in CPGs. The limitations of the journal layout may also devote to poor reporting. However, we believe that improved reporting of the details of the review and quality assurance methods will reinforce the transparency of review process, thereby improving the overall quality of the CPGs.

Only one CPG described the role of the funders in the development, dissemination and implementation of the guideline. This finding may reflect a lack of awareness among CPG developers on the importance of the dissemination and implementation strategies. Adequate dissemination and implementation strategies can improve the behavior of health care providers and consequently patient outcomes (67).

CPGs developed by Chinese institutions and published in Chinese-language journals had generally low reporting quality. This result is consistent with previous studies that have revealed the lower methodological quality of Chinese CPGs (68). The poor quality may raise concerns about the true value of Chinese CPGs. An exception was the PanAsian adapted CPG for the management of patients with NSCLC, a guideline initiated by the Chinese Society of Clinical Oncology (CSCO) and European Society of Medical Oncology (ESMO), which was published in a high-impact journal and had a good reporting quality (24). Nevertheless, Chinese developers should strengthen the rigor and applicability in the development of guidelines, to provide better recommendations and medical service in China.

\section{Limitations}

Our study has several limitations. First, we only included CPGs published in English and Chinese between the years 2018 and 2020. Second, the RIGHT checklist is intended to assess only the reporting quality. This assessment does, thus, not reflect the quality of the recommendations or the strength of the evidence, or the overall quality of the guideline. Third, we rated all items using a dichotomous scale; bias was inevitable when rating items that in reality were partially reported. However, we do not believe this is a substantial contributor to the inconsistent results across guidelines. Fourth, our review was limited to descriptive analyses. Because of the expected small number of guidelines, we did not conduct a regression analysis to study associations between the characteristics and reporting quality. Finally, we found no previously published studies evaluating the reporting quality of lung cancer guidelines, and we were thus unable to examine whether the launching of the RIGHT instrument improved the reporting quality.

\section{Questions to be further discussed and considered}

\section{Question 1: What impact do you think the low} reporting quality of clinical practice guidelines on lung neoplasms will have on clinicians and clinical practices? Expert opinion: Dr. Florian Kocher and Dr. Andreas Seeber The ultimate goal of CPGs is to guide treatment in clinical practice and therefore have a strong impact on medical decisions. According to an early study, it was 
Table 2 The reporting rates of each RIGHT checklist item in the eligible CPGs (9)

\begin{tabular}{|c|c|c|c|c|c|}
\hline Section/topic & No. & Item & $\begin{array}{l}\text { Reported, } \\
\text { n (\%) }\end{array}$ & $\begin{array}{c}\text { Not reported, } \\
\mathrm{n}(\%)\end{array}$ & $\begin{array}{c}\text { Not applicable, } \\
n(\%)\end{array}$ \\
\hline \multicolumn{6}{|l|}{ Basic information } \\
\hline Title/subtitle & $1 b$ & Describe the year of publication of the guideline & $18(36.7)$ & $31(63.3)$ & $0(0)$ \\
\hline Executive summary & 2 & $\begin{array}{l}\text { Provide a summary of the recommendations contained } \\
\text { in the guideline }\end{array}$ & $21(42.9)$ & $28(57.1)$ & $0(0)$ \\
\hline $\begin{array}{l}\text { Abbreviations and } \\
\text { acronyms }\end{array}$ & 3 & $\begin{array}{l}\text { Define new or key terms, and provide a list of } \\
\text { abbreviations and acronyms if applicable }\end{array}$ & $49(100.0)$ & $0(0)$ & $0(0)$ \\
\hline \multicolumn{6}{|l|}{ Background } \\
\hline $\begin{array}{l}\text { Brief description } \\
\text { of the health } \\
\text { problem(s) }\end{array}$ & 5 & $\begin{array}{l}\text { Describe the basic epidemiology of the problem, such } \\
\text { as the prevalence/incidence, morbidity, mortality, and } \\
\text { burden (including financial) resulting from the problem }\end{array}$ & $43(87.8)$ & $6(12.2)$ & $0(0)$ \\
\hline $\begin{array}{l}\text { Aim(s) of the } \\
\text { guideline and } \\
\text { specific objectives }\end{array}$ & 6 & $\begin{array}{l}\text { Describe the aim(s) of the guideline and specific } \\
\text { objectives, such as improvements in health indicators } \\
\text { (e.g., mortality and disease prevalence), quality of life, } \\
\text { or cost savings }\end{array}$ & $47(95.9)$ & $2(4.1)$ & $0(0)$ \\
\hline Target population(s) & $7 a$ & $\begin{array}{l}\text { Describe the primary population(s) that is affected by } \\
\text { the recommendation(s) in the guideline }\end{array}$ & $49(100.0)$ & $0(0)$ & $0(0)$ \\
\hline $\begin{array}{l}\text { End users and } \\
\text { settings }\end{array}$ & $8 b$ & $\begin{array}{l}\text { Describe the setting(s) for which the guideline is } \\
\text { intended, such as primary care, low- and middle- } \\
\text { income countries, or inpatient facilities }\end{array}$ & $26(53.1)$ & $23(46.9)$ & $0(0)$ \\
\hline \multirow[t]{2}{*}{$\begin{array}{l}\text { Guideline } \\
\text { development } \\
\text { groups }\end{array}$} & $9 a$ & $\begin{array}{l}\text { Describe how all contributors to the guideline } \\
\text { development were selected and their roles and } \\
\text { responsibilities (e.g., steering group, guideline panel, } \\
\text { external reviewers, systematic review team, and } \\
\text { methodologists) }\end{array}$ & $29(59.2)$ & $20(40.8)$ & $0(0)$ \\
\hline & $9 b$ & $\begin{array}{l}\text { List all individuals involved in developing the guideline, } \\
\text { including their title, role(s), and institutional affiliation(s) }\end{array}$ & $45(91.8)$ & $4(8.2)$ & $0(0)$ \\
\hline \multicolumn{6}{|l|}{ Evidence } \\
\hline $\begin{array}{l}\text { Health care } \\
\text { questions }\end{array}$ & $10 a$ & $\begin{array}{l}\text { State the key questions that were the basis for the } \\
\text { recommendations in PICO (population, intervention, } \\
\text { comparator, and outcome) or other format as appropriate }\end{array}$ & $22(44.9)$ & $27(55.1)$ & $0(0)$ \\
\hline
\end{tabular}

Table 2 (continued) 
Table 2 (continued)

\begin{tabular}{|c|c|c|c|c|c|}
\hline Section/topic & No. & Item & $\begin{array}{l}\text { Reported, } \\
\text { n (\%) }\end{array}$ & $\begin{array}{l}\text { Not reported, } \\
\mathrm{n}(\%)\end{array}$ & $\begin{array}{l}\text { Not applicable, } \\
\mathrm{n}(\%)\end{array}$ \\
\hline & $10 b$ & Indicate how the outcomes were selected and sorted & $13(26.5)$ & $36(73.5)$ & $0(0)$ \\
\hline $\begin{array}{l}\text { Assessment of the } \\
\text { certainty of the } \\
\text { body of evidence }\end{array}$ & 12 & $\begin{array}{l}\text { Describe the approach used to assess the certainty of } \\
\text { the body of evidence. }\end{array}$ & $24(49.0)$ & $25(51.0)$ & $0(0)$ \\
\hline \multirow[t]{3}{*}{ Recommendations } & $13 a$ & Provide clear, precise, and actionable recommendations & $49(100.0)$ & $0(0)$ & $0(0)$ \\
\hline & $13 b$ & $\begin{array}{l}\text { Present separate recommendations for important } \\
\text { subgroups if the evidence suggests that there } \\
\text { are important differences in factors influencing } \\
\text { recommendations, particularly the balance of benefits } \\
\text { and harms across subgroups }\end{array}$ & $45(91.8)$ & $4(8.2)$ & $0(0)$ \\
\hline & $13 c$ & $\begin{array}{l}\text { Indicate the strength of recommendations and the } \\
\text { certainty of the supporting evidence }\end{array}$ & $25(51.0)$ & $2(4.1)$ & $22(44.9)$ \\
\hline \multirow[t]{2}{*}{$\begin{array}{l}\text { Rationale/ } \\
\text { explanation for } \\
\text { recommendations }\end{array}$} & $14 a$ & $\begin{array}{l}\text { Describe whether values and preferences of the target } \\
\text { population(s) were considered in the formulation of } \\
\text { each recommendation. If yes, describe the approaches } \\
\text { and methods used to elicit or identify these values } \\
\text { and preferences. If values and preferences were not } \\
\text { considered, provide an explanation }\end{array}$ & $23(46.9)$ & $26(53.1)$ & $0(0)$ \\
\hline & $14 \mathrm{c}$ & $\begin{array}{l}\text { Describe other factors taken into consideration when } \\
\text { formulating the recommendations, such as equity, } \\
\text { feasibility, and acceptability }\end{array}$ & $7(14.3)$ & $42(85.7)$ & $0(0)$ \\
\hline $\begin{array}{l}\text { Evidence to } \\
\text { decision processes }\end{array}$ & 15 & $\begin{array}{l}\text { Describe the processes and approaches used by } \\
\text { the guideline development group to make decisions, } \\
\text { particularly the formulation of recommendations (such } \\
\text { as how consensus was defined and achieved and } \\
\text { whether voting was used) }\end{array}$ & $19(38.8)$ & $30(61.2)$ & $0(0)$ \\
\hline \multicolumn{6}{|c|}{ Review and quality assurance } \\
\hline External review & 16 & $\begin{array}{l}\text { Indicate whether the draft guideline underwent } \\
\text { independent review and, if so, how this was executed } \\
\text { and the comments considered and addressed. }\end{array}$ & $11(22.4)$ & $38(77.6)$ & $0(0)$ \\
\hline
\end{tabular}

Table 2 (continued) 
Table 2 (continued)

\begin{tabular}{|c|c|c|c|c|c|}
\hline Section/topic & No. & Item & $\begin{array}{l}\text { Reported, } \\
\text { n (\%) }\end{array}$ & $\begin{array}{l}\text { Not reported, } \\
\text { n (\%) }\end{array}$ & $\begin{array}{l}\text { Not applicable, } \\
\mathrm{n}(\%)\end{array}$ \\
\hline Quality assurance & 17 & $\begin{array}{l}\text { Indicate whether the guideline was subjected to a } \\
\text { quality assurance process. If yes, describe the process. }\end{array}$ & $1(2.0)$ & $48(98.0)$ & $0(0)$ \\
\hline \multicolumn{6}{|c|}{ Funding and declaration and management of interests } \\
\hline \multirow{2}{*}{$\begin{array}{l}\text { Funding source(s) } \\
\text { and role(s) of the } \\
\text { funder }\end{array}$} & $18 \mathrm{a}$ & $\begin{array}{l}\text { Describe the specific sources of funding for all stages of } \\
\text { guideline development. }\end{array}$ & $19(38.8)$ & $30(61.2)$ & $0(0)$ \\
\hline & $18 \mathrm{~b}$ & $\begin{array}{l}\text { Describe the role of funder(s) in the different stages of } \\
\text { guideline development and in the dissemination and } \\
\text { implementation of the recommendations. }\end{array}$ & $1(2.0)$ & $14(28.6)$ & $34(69.4)$ \\
\hline $\begin{array}{l}\text { Declaration and } \\
\text { management of } \\
\text { interests }\end{array}$ & $19 a$ & $\begin{array}{l}\text { Describe what types of conflicts (financial and } \\
\text { nonfinancial) were relevant to guideline development. }\end{array}$ & $39(79.6)$ & $10(20.4)$ & $0(0)$ \\
\hline \multicolumn{6}{|l|}{ Other information } \\
\hline Access & 20 & $\begin{array}{l}\text { Describe where the guideline, its appendices, and other } \\
\text { related documents can be accessed. }\end{array}$ & $8(16.3)$ & $41(83.7)$ & $0(0)$ \\
\hline $\begin{array}{l}\text { Suggestions for } \\
\text { further research }\end{array}$ & 21 & $\begin{array}{l}\text { Describe the gaps in the evidence and/or provide } \\
\text { suggestions for future research. }\end{array}$ & $25(51.0)$ & $24(49.0)$ & $0(0)$ \\
\hline $\begin{array}{l}\text { Limitations of the } \\
\text { guideline }\end{array}$ & 22 & $\begin{array}{l}\text { Describe any limitations in the guideline development } \\
\text { process (such as the development groups were not } \\
\text { multidisciplinary or patients' values and preferences } \\
\text { were not sought), and indicate how these limitations } \\
\text { might have affected the validity of the recommendations. }\end{array}$ & $23(46.9)$ & $26(53.1)$ & $0(0)$ \\
\hline
\end{tabular}

RIGHT, Reporting Items for Practice Guidelines in Healthcare; CPGs, clinical practice guidelines. Details of the RIGHT checklist is available on: http://www.right-statement.org/right-statement/checklist.

assumed that low quality guidelines may cause harm to patients and might waste medical resources (69). It can be assumed that the quality of guidelines, regarding formal aspects and content, have improved within the last decades. In our point of view, the RIGHT standards and AGREE II (70) are powerful tools to improve and measure quality of CPGs. With regard to lung cancer, guidelines we found a mean overall reporting proportion of $57.9 \%$. This implicates that further improvements are necessary to enhance quality. In 2016, Heins et al. (71) evaluated adherence to cancer guidelines in the Netherlands. Interestingly, adherence to the different treatment guidelines ranged widely between the different cancer entities. Adherence to guidelines regarding lung cancer was substantially lower (57\%) compared to recommendations on treatment of malignant melanoma (99\%). A recently published study evaluated the reporting quality using the RIGHT statement across cancer guidelines of the NCCN (72). The highest reporting proportion was observed for the acute lymphoblastic leukemia guideline (60.0\%) followed by melanoma, amyloidosis, B-cell neoplasms, anal cancer, colorectal cancer (58.6\%, each). The reporting proportion for NSCLC and SCLC was slightly lower with $55.7 \%$ and $52.9 \%$, respectively. To the best of our knowledge, the association between quality of CPGs and their impact on clinical decision making have not been studied so far. However, increased adherence to guidelines due to improvements in GPCs reporting quality is conceivable.

\section{Expert opinion: Dr. Cesare Gridelli}

Often this is cause of low adherence to guidelines by physicians with patients undertreated. For instance is well known the low adherence to concurrent chemo-radiation in locally advanced NSCLC or limited SCLC favouring often 

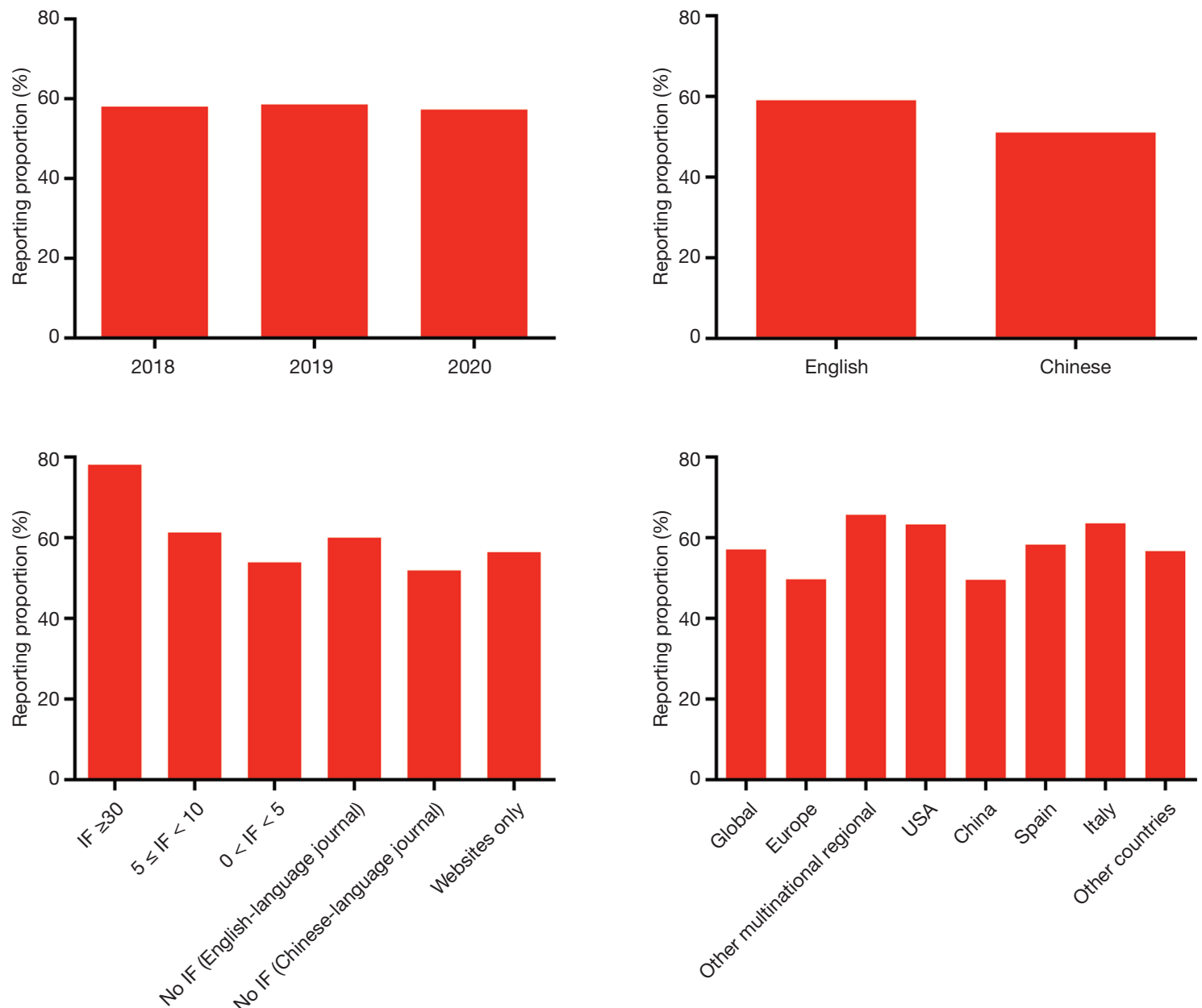

Figure 3 The reporting proportion of included clinical practice guidelines in the stratified analyses. IF, impact factor.

an inappropriate sequential approach.

\section{Expert opinion: Dr. Mariano Provencio}

It is essential to have a high level of quality and to follow the recommendations for the elaboration of clinical practice guidelines, if these do not follow quality control they will lose credibility for the readers.

\section{Expert opinion: Dr. Nobubiko Seki}

Guidelines are the most important indicators for practicing standard treatment.

In terms of 'Evidence', if the balance between toxicity and efficacy and the balance between cost and efficacy are not sufficiently examined, only the expectation for the efficacy may be left alone and therefore patients are more likely to suffer from toxicity and cost.

In addition, even if the treatment has not been established as effective, once it is recommended by the guidelines, doctors are more likely to practice the treatment easily, and many patients will continue to be disadvantaged.

Also, from the perspective of 'Review and quality assurance' and 'Funding and declaration and management of COI', there is an increased risk that treatment recommendations based on misinterpretations or arbitrary judgments will be used as the established guideline.

\section{Expert opinion: Dr. Yusuke Tomita}

The low reporting quality of clinical practice guidelines on lung neoplasms may mislead clinicians and may negatively impact on patients' clinical course

Question 2: What do you think the most important aspects needed for developing high-quality clinical practice guidelines on lung neoplasms are?

Expert opinion: Dr. Florian Kocher and Dr. Andreas Seeber

We assume that adherence to the STRING statement 
facilitates development of high-quality CPGs. Therefore, the checklist should be taken into account prior to the developmental process. Another important aspect is a holistic review of the available literature and timely incorporation of new and practice changing results. For this reason, it should be stated whether the information is based on new systematic reviews or already existing literature and should provide the search strategy to improve transparency. With respect to CPGs dealing with lung cancer treatment, a lack of information was observed. To decipher the value of certain recommendations, the level of evidence has to be provided to draw certain conclusions in the clinical routine.

According to our analysis, the year of publication was reported in only $36.7 \%$ of guidelines. Thus, it might be challenging to capture the recentness of the included evidence for the readership and might lead to obsolete treatment algorithms. Therefore, the inclusion of the year published is highly recommended. Finally, guidelines should take into account different local capabilities (i.e., low income countries) to allow optimal patient care.

\section{Expert opinion: Dr. Cesare Gridelli}

One of the most important aspects is the multidisciplinary team of panelists in particularly in the early stages and locally advanced disease. Some associations (thoracic surgeons, radiotherapists, medical oncologists) have an own vision that need to be shared with other physician categories (including pathologists, radiologists, pneumologists and others). Furthermore, high quality processes should consider assessment evaluations of adherence to guidelines.

\section{Expert opinion: Dr. Mariano Provencio}

Medical journals should reject and be more selective in accepting clinical practice guidelines for publication if they do not follow adequate quality parameters. The importance and influence of guidelines on clinicians is enormous and if they are based on insufficiently supported data, they can cause terrible damage.

\section{Expert opinion: Dr. Nobubiko Seki}

I think it is the most important to clarify the ranking of how important the 7 domains included in the RIGHT checklist are in order to develop high-quality guidelines in clinical practice.

In my opinion, 'Evidence' domain is the most important part of the RIGHT checklist and is the basis for delivering truly scientifically effective treatments to patients.

I think the next most important domain after 'Evidence' is 'Recommendations'.

If this quality is not maintained, such guidelines will not be useful for patients' treatment choices in various clinical settings.

In addition, by clarifying the process of discussion up to the decision of the recommendation level in the guidelines, I think doctors are more likely to choose the more appropriate treatment even if they are uncertain about the treatment choice.

However, I was very surprised to see the results of these reporting rates of 'Evidence' and 'Recommendations'.

Of the 12 items included in these 2 domains, 8 items had reporting rates of less than $50 \%$.

On the other hand, in my opinion, the 5 domains other than 'Evidence' and 'Recommendations' are primarily responsible for supporting the quality of these 2 domains.

\section{Expert opinion: Dr. Yusuke Tomita}

Currently, new drugs and new treatment options for lung neoplasms are frequently approved. Therefore, the frequent update of clinical practice guidelines are required.

\section{Question 3: How do you think conflicts of interest in the guidelines should be handled? Expert opinion: Dr. Florian Kocher and Dr. Andreas Seeber}

The readership of CPGs should be made aware of funding sources and potential conflicts of interest. The role of funding, in particular, was provided in only one guideline. Nevertheless, this topic is important since it improves transparency and helps the readers to acknowledge such conflicts and potential bias. If such information is not provided it might question the integrity and quality of the provided guideline.

\section{Expert opinion: Dr. Cesare Gridelli}

On my opinion conflict of interests should be declared by the Guidelines Panelists but not should be a limitation in case of usual fees from companies for advisory board, speaker bureau and consultant activities

\section{Expert opinion: Dr. Mariano Provencio}

The reporting of conflicts of interest should be mandatory and cause for rejection if they are not well documented or if any anomaly is detected. Independence in the preparation of these reports necessarily requires transparency in the reporting of conflicts of interest.

\section{Expert opinion: Dr. Nobubiko Seki}

In my opinion, as mentioned in Question 2, conflicts of interest are primarily responsible for supporting the quality of the domains of 'Evidence' and 'Recommendations'. However, there is no change in the importance.

(I) The funding for the development of the guidelines should be provided by the academic society, not by 
any external organizations.

(II) Persons with conflicts of interest above the specified level should not be involved in guideline development work.

(III) Even if the conflicts of interest falls within the specified range, the committee members involved in the development of the guidelines should publish the conflicts of interest for at least the past three years and be reviewed and approved by the conflicts of interest management committee of the academic society.

\section{Expert opinion: Dr. Yusuke Tomita}

Conflicts of interest status of all authors who involved in the guideline development should be disclosed.

\section{Conclusions}

In summary, this analysis revealed that reporting in CPGs for lung cancer is suboptimal, although some domains were relatively well reported. In particular, the reporting of the independent review and quality assurance process needs to be improved.

\section{Acknowledgments}

The authors appreciate the academic support from the AME Reporting Guideline Collaborative Group.

Funding: This work was supported by the National Science and Technology Major Project of China (grant number 2020ZX09201009).

\section{Footnote}

Conflicts of Interest: All authors have completed the ICMJE uniform disclosure form (available at https://dx.doi. org/10.21037/tlcr-21-405). NS obtained commercial research grants from Eli Lilly, Chugai Pharmaceutical, Taiho Pharmaceutical, Pfizer Japan, Ono Pharmaceutical, and Nippon Boehringer Ingelheim, and has received speaking honoraria from Eli Lilly, AstraZeneca, MSD Oncology, Chugai Pharmaceutical, Taiho Pharmaceutical, Pfizer Japan, Ono Pharmaceutical, Nippon Boehringer Ingelheim, and Bristol-Myers Squibb Japan. The other authors have no conflicts of interest to declare.

Ethical Statement: The authors are accountable for all aspects of the work in ensuring that questions related to the accuracy or integrity of any part of the work are appropriately investigated and resolved.

Open Access Statement: This is an Open Access article distributed in accordance with the Creative Commons Attribution-NonCommercial-NoDerivs 4.0 International License (CC BY-NC-ND 4.0), which permits the noncommercial replication and distribution of the article with the strict proviso that no changes or edits are made and the original work is properly cited (including links to both the formal publication through the relevant DOI and the license). See: https://creativecommons.org/licenses/by-nc-nd/4.0/.

\section{References}

1. Ferlay J, Soerjomataram I, Dikshit R, et al. Cancer incidence and mortality worldwide: sources, methods and major patterns in GLOBOCAN 2012. Int J Cancer 2015;136:E359-86.

2. Bray F, Ferlay J, Soerjomataram I, et al. Global cancer statistics 2018: GLOBOCAN estimates of incidence and mortality worldwide for 36 cancers in 185 countries. CA Cancer J Clin 2018;68:394-424.

3. Howlader N, Forjaz G, Mooradian MJ, et al. The Effect of Advances in Lung-Cancer Treatment on Population Mortality. N Engl J Med 2020;383:640-9.

4. Pennell NA, Arcila ME, Gandara DR, et al. Biomarker Testing for Patients With Advanced Non-Small Cell Lung Cancer: Real-World Issues and Tough Choices. Am Soc Clin Oncol Educ Book 2019;39:531-42.

5. Peters S, Reck M, Smit EF, et al. How to make the best use of immunotherapy as first-line treatment of advanced/ metastatic non-small-cell lung cancer. Ann Oncol 2019;30:884-96.

6. Shekelle PG, Ortiz E, Rhodes S, et al. Validity of the Agency for Healthcare Research and Quality clinical practice guidelines: how quickly do guidelines become outdated? JAMA 2001;286:1461-7.

7. Shekelle P, Eccles MP, Grimshaw JM, et al. When should clinical guidelines be updated? BMJ 2001;323:155-7.

8. Pavlidis N, Hansen H, Stahel R. ESMO clinical recommendations: using the easier and faster approach to oncology guidelines. Ann Oncol 2009;20 Suppl 4:7-9.

9. Chen Y, Yang K, Marusic A, et al. A Reporting Tool for Practice Guidelines in Health Care: The RIGHT Statement. Ann Intern Med 2017;166:128-32.

10. Clinical practice guideline for radiation therapy in small cell lung cancer (2020 version). Chinese Journal of Radiation Oncology 2020;29:608-14. 
11. Singh S, Bergsland EK, Card CM, et al. Commonwealth Neuroendocrine Tumour Research Collaboration and the North American Neuroendocrine Tumor Society Guidelines for the Diagnosis and Management of Patients With Lung Neuroendocrine Tumors: An International Collaborative Endorsement and Update of the 2015 European Neuroendocrine Tumor Society Expert Consensus Guidelines. J Thorac Oncol 2020;15:1577-98.

12. Le Pechoux C, Faivre-Finn C, Ramella S, et al. ESTRO ACROP guidelines for target volume definition in the thoracic radiation treatment of small cell lung cancer. Radiother Oncol 2020;152:89-95.

13. Sun A, Durocher-Allen LD, Ellis PM, et al. Guideline for the Initial Management of Small Cell Lung Cancer (Limited and Extensive Stage) and the Role of Thoracic Radiotherapy and First-line Chemotherapy. Clin Oncol (R Coll Radiol) 2018;30:658-66.

14. Simone CB, 2nd, Bogart JA, Cabrera AR, et al. Radiation Therapy for Small Cell Lung Cancer: An ASTRO Clinical Practice Guideline. Pract Radiat Oncol 2020;10:158-73.

15. Gonzalez-Flores E, Serrano R, Sevilla I, et al. SEOM clinical guidelines for the diagnosis and treatment of gastroenteropancreatic and bronchial neuroendocrine neoplasms (NENs) (2018). Clin Transl Oncol 2019;21:55-63.

16. Domine M, Moran T, Isla D, et al. SEOM clinical guidelines for the treatment of small-cell lung cancer (SCLC) (2019). Clin Transl Oncol 2020;22:245-55.

17. Zhang XC, Lu S, Zhang L, et al. Guidenline for diagnosis and treatment of Alk and Ros1 positive non-small cell lung cancer in China. Zhonghua Bing Li Xue Za Zhi 2018;47:241-7.

18. Clinical practice guideline for radiation therapy of nonsmall cell lung cancer (2020 version). Chinese Journal of Radiation Oncology 2020;29:599-607.

19. Facchinetti F, Pilotto S, Metro G, et al. Treatment of metastatic non-small cell lung cancer: 2018 guidelines of the Italian Association of Medical Oncology (AIOM). Tumori 2019;105:3-14.

20. Passiglia F, Pilotto S, Facchinetti F, et al. Treatment of advanced non-small-cell lung cancer: The 2019 AIOM (Italian Association of Medical Oncology) clinical practice guidelines. Crit Rev Oncol Hematol 2020;146:102858.

21. Hanna NH, Schneider BJ, Temin S, et al. Therapy for Stage IV Non-Small-Cell Lung Cancer Without Driver Alterations: ASCO and $\mathrm{OH}$ (CCO) Joint Guideline Update. J Clin Oncol 2020;38:1608-32.

22. Majem M, Juan O, Insa A, et al. SEOM clinical guidelines for the treatment of non-small cell lung cancer (2018). Clin Transl Oncol 2019;21:3-17.

23. Park K, Vansteenkiste J, Lee KH, et al. Pan-Asian adapted ESMO Clinical Practice Guidelines for the management of patients with locally-advanced unresectable non-smallcell lung cancer: a KSMO-ESMO initiative endorsed by CSCO, ISMPO, JSMO, MOS, SSO and TOS. Ann Oncol 2020;31:191-201.

24. Wu YL, Planchard D, Lu S, et al. Pan-Asian adapted Clinical Practice Guidelines for the management of patients with metastatic non-small-cell lung cancer: a CSCO-ESMO initiative endorsed by JSMO, KSMO, MOS, SSO and TOS. Ann Oncol 2019;30:171-210.

25. Ponce S, Bruna J, Juan O, et al. Multidisciplinary expert opinion on the treatment consensus for patients with EGFR mutated NSCLC with brain metastases. Crit Rev Oncol Hematol 2019;138:190-206.

26. Planchard D, Popat S, Kerr K, et al. Metastatic non-small cell lung cancer: ESMO Clinical Practice Guidelines for diagnosis, treatment and follow-up. Ann Oncol 2018;29:iv192-iv237.

27. Akamatsu H, Ninomiya K, Kenmotsu H, et al. The Japanese Lung Cancer Society Guideline for non-small cell lung cancer, stage IV. Int J Clin Oncol 2019;24:731-70.

28. Ettinger DS, Wood DE, Aisner DL, et al. Non-Small Cell Lung Cancer, NCCN Guidelines Version 8.2020. Available online: https://www.nccn.org/professionals/ physician_gls/default.aspx

29. Nestle U, De Ruysscher D, Ricardi U, et al. ESTRO ACROP guidelines for target volume definition in the treatment of locally advanced non-small cell lung cancer. Radiother Oncol 2018;127:1-5.

30. Berman AT, Jabbour SK, Vachani A, et al. Empiric Radiotherapy for Lung Cancer Collaborative Group multi-institutional evidence-based guidelines for the use of empiric stereotactic body radiation therapy for non-small cell lung cancer without pathologic confirmation. Transl Lung Cancer Res 2019;8:5-14.

31. Passiglia F, Bertolaccini L, Del Re M, et al. Diagnosis and treatment of early and locally advanced non-smallcell lung cancer: The 2019 AIOM (Italian Association of Medical Oncology) clinical practice guidelines. Crit Rev Oncol Hematol 2020;148:102862.

32. De Marinis F, Barberis M, Barbieri V, et al. Diagnosis and first-line treatment of non-small cell lung cancer in the era of novel immunotherapy: recommendations for clinical practice. Expert Rev Respir Med 2019;13:217-28.

33. Chinese society of clinical oncology. Guidelines for 
diagnosis and treatment of non-small cell lung cancer (2020). Available online: http://med.china.com.cn/content/ $\mathrm{pid} / 191547 / \mathrm{tid} / 1026$.

34. Prabhash K, Advani SH, Batra U, et al. Biomarkers in NonSmall Cell Lung Cancers: Indian Consensus Guidelines for Molecular Testing. Adv Ther 2019;36:766-85.

35. Chen L, Smith DA, Somarouthu B, et al. A Radiologist's Guide to the Changing Treatment Paradigm of Advanced Non-Small Cell Lung Cancer: The ASCO 2018 Molecular Testing Guidelines and Targeted Therapies. AJR Am J Roentgenol 2019;213:1047-58.

36. Garrido P, Conde E, de Castro J, et al. Updated guidelines for predictive biomarker testing in advanced non-smallcell lung cancer: a National Consensus of the Spanish Society of Pathology and the Spanish Society of Medical Oncology. Clin Transl Oncol 2020;22:989-1003.

37. Dingemans AC, Soo RA, Jazieh AR, et al. Treatment Guidance for Patients With Lung Cancer During the Coronavirus 2019 Pandemic. J Thorac Oncol 2020;15:1119-36.

38. Arrieta O, Cardona AF, Lara-Mejia L, et al. Recommendations for detection, prioritization, and treatment of thoracic oncology patients during the COVID-19 pandemic: the THOCOoP cooperative group. Crit Rev Oncol Hematol 2020;153:103033.

39. Chinese guidelines for diagnosis and treatment of primary lung cancer 2018 (English version). Chin J Cancer Res 2019;31:1-28.

40. Schneider BJ, Ismaila N, Aerts J, et al. Lung Cancer Surveillance After Definitive Curative-Intent Therapy: ASCO Guideline. J Clin Oncol 2020;38:753-66.

41. Baldotto C, Gelatti A, Accioly A, et al. Lung Cancer and the COVID-19 pandemic: Recommendations from the Brazilian Thoracic Oncology Group. Clinics (Sao Paulo) 2020;75:e2060.

42. Travis WD, Dacic S, Wistuba I, et al. IASLC Multidisciplinary Recommendations for Pathologic Assessment of Lung Cancer Resection Specimens After Neoadjuvant Therapy. J Thorac Oncol 2020;15:709-40.

43. Passaro A, Addeo A, Von Garnier C, et al. ESMO Management and treatment adapted recommendations in the COVID-19 era: Lung cancer. ESMO Open 2020;5:e000820.

44. Chinese Medical Association guidelines for clinical diagnosis and treatment of lung cancer (2019 edition). Chinese Journal of Oncology 2020;42:257-87.

45. de Groot PM, Chung JH, Ackman JB, et al. ACR Appropriateness Criteria((R)) Noninvasive Clinical
Staging of Primary Lung Cancer. J Am Coll Radiol 2019;16:S184-95.

46. Clinical practice guideline for stage IV primary lung cancer in China(2020 version). Chinese Journal of Oncology 2020;42:1-16.

47. NICE guideline. Lung cancer: diagnosis and management (NG122). Available online: http://nice.org.uk/guidance/ ng122

48. Yatabe Y, Dacic S, Borczuk AC, et al. Best Practices Recommendations for Diagnostic Immunohistochemistry in Lung Cancer. J Thorac Oncol 2019;14:377-407.

49. Kalemkerian GP, Narula N, Kennedy EB, et al. Molecular Testing Guideline for the Selection of Patients With Lung Cancer for Treatment With Targeted Tyrosine Kinase Inhibitors: American Society of Clinical Oncology Endorsement of the College of American Pathologists/ International Association for the Study of Lung Cancer/ Association for Molecular Pathology Clinical Practice Guideline Update. J Clin Oncol 2018;36:911-9.

50. Lindeman NI, Cagle PT, Aisner DL, et al. Updated Molecular Testing Guideline for the Selection of Lung Cancer Patients for Treatment With Targeted Tyrosine Kinase Inhibitors: Guideline From the College of American Pathologists, the International Association for the Study of Lung Cancer, and the Association for Molecular Pathology. Arch Pathol Lab Med 2018;142:321-46.

51. Donnelly EF, Kazerooni EA, Lee E, et al. ACR Appropriateness Criteria((R)) Lung Cancer Screening. J Am Coll Radiol 2018;15:S341-6.

52. Zhou Q, Fan Y, Wang Y, et al. China National Lung Cancer Screening Guideline with Low-dose Computed Tomography (2018 version). Chinese Journal of Lung Cancer 2018;21:67-75.

53. Wood DE, Kazerooni EA, Baum SL, et al. Lung Cancer Screening, NCCN Guidelines Version 1.2020. Available online: https://www.nccn.org/default.aspx

54. Mazzone PJ, Gould MK, Arenberg DA, et al. Management of Lung Nodules and Lung Cancer Screening During the COVID-19 Pandemic: CHEST Expert Panel Report. J Am Coll Radiol 2020;17:845-54.

55. Veronesi G, Baldwin DR, Henschke CI, et al. Recommendations for Implementing Lung Cancer Screening with Low-Dose Computed Tomography in Europe. Cancers (Basel) 2020;12:1672.

56. Koegelenberg CFN, Dorfman S, Schewitz I, et al. Recommendations for lung cancer screening in Southern Africa. J Thorac Dis 2019;11:3696-703.

57. Jazieh AR, AlGhamdi M, AlGhanem S, et al. Saudi lung 
cancer prevention and screening guidelines. Ann Thorac Med 2018;13:198-204.

58. Mazzone PJ, Silvestri GA, Patel S, et al. Screening for Lung Cancer: CHEST Guideline and Expert Panel Report. Chest 2018;153:954-85.

59. Shah MA, Oliver TK, Peterson DE, et al. ASCO Clinical Practice Guideline Endorsements and Adaptations. J Clin Oncol 2020;38:834-40.

60. Xiao Y, Jiang L, Tong Y, et al. Evaluation of the quality of guidelines for assisted reproductive technology using the RIGHT checklist: A cross-sectional study. Eur J Obstet Gynecol Reprod Biol 2019;241:42-8.

61. Zhao S, Cao J, Shi Q, et al. A quality evaluation of guidelines on five different viruses causing public health emergencies of international concern. Ann Transl Med 2020;8:500.

62. Eguchi T, Bains S, Lee MC, et al. Impact of Increasing Age on Cause-Specific Mortality and Morbidity in Patients With Stage I Non-Small-Cell Lung Cancer: A Competing Risks Analysis. J Clin Oncol 2017;35:281-90.

63. Karanth S, Rajan SS, Sharma G, et al. Racial-Ethnic Disparities in End-of-Life Care Quality among Lung Cancer Patients: A SEER-Medicare-Based Study. J Thorac Oncol 2018;13:1083-93.

64. Johnson FE, Naunheim KS, Coplin MA, et al. Geographic variation in the conduct of patient surveillance after lung cancer surgery. J Clin Oncol 1996;14:2940-9.

65. Nadler E, Espirito JL, Pavilack M, et al. Treatment Patterns and Clinical Outcomes Among Metastatic

Cite this article as: Yang Y, Lu J, Ma Y, Xi C, Kang J, Zhang Q, Jia X, Liu K, Du S, Kocher F, Seeber A, Gridelli C, Provencio M, Seki N, Tomita Y, Zhang X. Evaluation of the reporting quality of clinical practice guidelines on lung cancer using the RIGHT checklist. Transl Lung Cancer Res 2021;10(6):2588-2602. doi: $10.21037 /$ tlcr-21-405
Non-Small-Cell Lung Cancer Patients Treated in the Community Practice Setting. Clin Lung Cancer 2018;19:360-70.

66. Aguiar PN, Jr., Haaland B, Park W, et al. Costeffectiveness of Osimertinib in the First-Line Treatment of Patients With EGFR-Mutated Advanced Non-Small Cell Lung Cancer. JAMA Oncol 2018;4:1080-4.

67. Tomasone JR, Kauffeldt KD, Chaudhary R, et al. Effectiveness of guideline dissemination and implementation strategies on health care professionals' behaviour and patient outcomes in the cancer care context: a systematic review. Implement Sci 2020;15:41.

68. Chen Y, Wang C, Shang H, et al. Clinical practice guidelines in China. BMJ 2018;360:j5158.

69. Shaneyfelt TM, Mayo-Smith MF, Rothwangl J. Are guidelines following guidelines? The methodological quality of clinical practice guidelines in the peer-reviewed medical literature. JAMA 1999;281:1900-5.

70. Brouwers MC, Kho ME, Browman GP, et al. AGREE II: advancing guideline development, reporting and evaluation in health care. CMAJ 2010;182:E839-42.

71. Heins MJ, de Jong JD, Spronk I, et al. Adherence to cancer treatment guidelines: influence of general and cancer-specific guideline characteristics. Eur J Public Health 2017;27:616-20.

72. Wayant C, Cooper C, Turner D, et al. Evaluation of the NCCN guidelines using the RIGHT Statement and AGREE-II instrument: a cross-sectional review. BMJ Evid Based Med 2019;24:219-26. 


\section{Appendix 1 Search Strateg}

\section{PubMed}

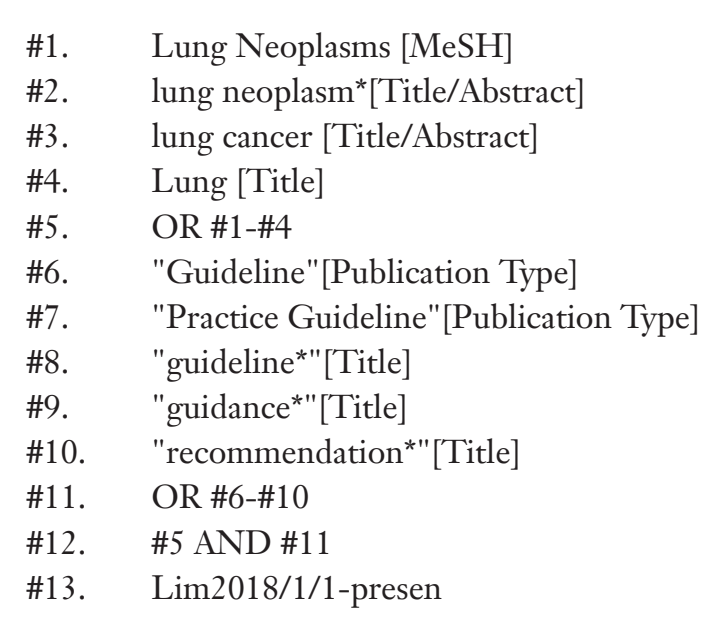

Table S1 Characteristics of the included guidelines

\begin{tabular}{|c|c|c|c|c|c|c|c|}
\hline No. & $\begin{array}{c}\text { Publication } \\
\text { language }\end{array}$ & $\begin{array}{l}\text { Country/ } \\
\text { region }\end{array}$ & $\begin{array}{l}\text { Histological } \\
\text { classification }\end{array}$ & $\begin{array}{c}\text { Year of } \\
\text { publication }\end{array}$ & Scope/purpose & Journal & Developers \\
\hline 1 (10) & Chinese & China & SCLC & 2020 & Treatment & $\begin{array}{l}\text { Chinese Journal of } \\
\text { Radiation Oncology }\end{array}$ & $\begin{array}{l}\text { CSTRO; CATRO; } \\
\text { CART; CSCO }\end{array}$ \\
\hline 2 (11) & English & Global & SCLC & 2020 & $\begin{array}{c}\text { Diagnosis and } \\
\text { management }\end{array}$ & J Thorac Oncol & $\begin{array}{l}\text { CommNETs/ } \\
\text { NANETS }\end{array}$ \\
\hline $3(12)$ & English & Europe & SCLC & 2020 & Treatment & Radiother Oncol & ESTRO ACROP \\
\hline $4(13)$ & English & Canada & SCLC & 2018 & Management & Clin Oncol & $\mathrm{CCO}$ \\
\hline 5 (14) & English & USA & SCLC & 2020 & Treatment & Pract Radiat Oncol & ASTRO \\
\hline 6 (15) & English & Spain & SCLC & 2018 & $\begin{array}{l}\text { Diagnosis and } \\
\text { treatment }\end{array}$ & Clin Transl Oncol & SEOM \\
\hline 7 (16) & English & Spain & SCLC & 2020 & Treatment & Clin Transl Oncol & SEOM \\
\hline $8(17)$ & Chinese & China & NSCLC & 2018 & $\begin{array}{l}\text { Diagnosis and } \\
\text { treatment }\end{array}$ & $\begin{array}{l}\text { Chinese Journal of } \\
\text { Pathology }\end{array}$ & $\operatorname{csco}$ \\
\hline 9 (18) & Chinese & China & NSCLC & 2020 & Treatment & $\begin{array}{l}\text { Chinese Journal of } \\
\text { Radiation Oncology }\end{array}$ & $\begin{array}{l}\text { CMA; CATRO; } \\
\text { CART; CSCO }\end{array}$ \\
\hline $10(19)$ & English & Italy & NSCLC & 2019 & Treatment & Tumori & AIOM \\
\hline $11(20)$ & English & Italy & NSCLC & 2020 & Treatment & $\begin{array}{l}\text { Crit Rev Oncol } \\
\text { Hematol }\end{array}$ & AIOM \\
\hline $12(21)$ & English & $\begin{array}{l}\text { North } \\
\text { America }\end{array}$ & NSCLC & 2020 & Treatment & J Clin Oncol & ASCO; OH(CCO) \\
\hline 13 (22) & English & Spain & NSCLC & 2019 & Treatment & Clin Transl Oncol & SEOM \\
\hline $14(23)$ & English & Pan-Asia & NSCLC & 2020 & Management & Ann Oncol & KSMO; ESMO \\
\hline $15(24)$ & English & Pan-Asia & NSCLC & 2019 & Management & Ann Oncol & CSCO; ESMO \\
\hline $16(25)$ & English & Spain & NSCLC & 2019 & Treatment & $\begin{array}{l}\text { Crit Rev Oncol } \\
\text { Hematol }\end{array}$ & $\begin{array}{l}\text { Multidisciplinary } \\
\text { group }\end{array}$ \\
\hline 17 (26) & English & Europe & NSCLC & 2019 & $\begin{array}{l}\text { Diagnosis and } \\
\text { treatment }\end{array}$ & Ann Oncol & ESMO \\
\hline $18(27)$ & English & Japan & NSCLC & 2019 & $\begin{array}{l}\text { Diagnosis and } \\
\text { treatment }\end{array}$ & Int J Clin Oncol & $\begin{array}{l}\text { Japan Lung } \\
\text { Cancer Society }\end{array}$ \\
\hline $19(28)$ & English & USA & NSCLC & 2020 & $\begin{array}{l}\text { Diagnosis and } \\
\text { treatment }\end{array}$ & NCCN website & NCCN \\
\hline $20(29)$ & English & Europe & NSCLC & 2018 & Diagnosis & Radiother Oncol & ESTRO; ACROP \\
\hline $21(30)$ & English & USA & NSCLC & 2019 & Treatment & $\begin{array}{c}\text { Trans/ Lung Cancer } \\
\text { Res }\end{array}$ & $\begin{array}{l}\text { Collaborative } \\
\text { group }\end{array}$ \\
\hline $22(31)$ & English & Italy & NSCLC & 2020 & $\begin{array}{l}\text { Diagnosis and } \\
\text { treatment }\end{array}$ & $\begin{array}{l}\text { Crit Rev Oncol } \\
\text { Hematol }\end{array}$ & AIOM \\
\hline $23(32)$ & English & Italy & NSCLC & 2019 & $\begin{array}{l}\text { Diagnosis and } \\
\text { treatment }\end{array}$ & $\begin{array}{l}\text { Expert Rev Respir } \\
\text { Med }\end{array}$ & $\begin{array}{l}\text { Multidisciplinary } \\
\text { group }\end{array}$ \\
\hline $24(33)$ & Chinese & China & NSCLC & 2020 & $\begin{array}{l}\text { Diagnosis and } \\
\text { treatment }\end{array}$ & $\begin{array}{l}\text { People's Medical } \\
\text { Publishing House }\end{array}$ & $\operatorname{csco}$ \\
\hline $25(34)$ & English & India & NSCLC & 2019 & Testing & Adv Ther & $\begin{array}{l}\text { Multidisciplinary } \\
\text { group }\end{array}$ \\
\hline $26(35)$ & English & USA & NSCLC & 2019 & Testing & $\begin{array}{l}\text { AJR Am J } \\
\text { Roentgenol }\end{array}$ & ASCO \\
\hline $27(36)$ & English & Spain & NSCLC & 2019 & Testing & Clin Transl Oncol & SEOM; SEAP \\
\hline $28(37)$ & English & Global & LC & 2020 & Treatment & $J$ Thorac Oncoly & $\begin{array}{l}\text { Multidisciplinary } \\
\text { group }\end{array}$ \\
\hline $29(38)$ & English & Global & LC & 2020 & $\begin{array}{l}\text { Diagnosis and } \\
\text { treatment }\end{array}$ & $\begin{array}{l}\text { Crit Rev Oncol } \\
\text { Hematol }\end{array}$ & Cooperative group \\
\hline $30(39)$ & English & China & LC & 2019 & Treatment & Chin $J$ Cancer Res & $\mathrm{NHC}$ \\
\hline $31(40)$ & English & USA & LC & 2019 & Treatment & $J$ Clin Oncol & ASCO \\
\hline $32(41)$ & English & Brazil & LC & 2020 & Management & Clinics & GBOT \\
\hline $33(42)$ & English & Global & LC & 2020 & Diagnosis & $J$ Thorac Oncoly & IASLC \\
\hline $34(43)$ & English & Europe & LC & 2020 & $\begin{array}{l}\text { Management and } \\
\text { treatment }\end{array}$ & ESMO Open & ESMO \\
\hline $35(44)$ & Chinese & China & LC & 2020 & $\begin{array}{l}\text { Diagnosis and } \\
\text { treatment }\end{array}$ & $\begin{array}{l}\text { Chinese Journal of } \\
\text { Oncology }\end{array}$ & CMA \\
\hline \multicolumn{4}{|c|}{ 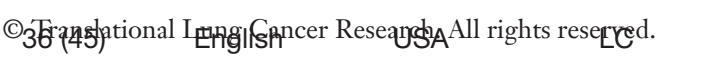 } & 2019 & Diagnosis & \multicolumn{2}{|c|}{ 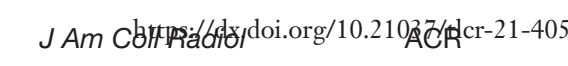 } \\
\hline $37(46)$ & Chinese & China & LC & 2020 & Treatment & $\begin{array}{l}\text { Chinese Journal of } \\
\text { Oncology }\end{array}$ & CEDA \\
\hline $38(47)$ & English & UK & LC & 2019 & $\begin{array}{l}\text { Diagnosis and } \\
\text { management }\end{array}$ & NICE website & NICE \\
\hline $39(48)$ & English & Global & LC & 2019 & Testing & J Thorac Oncol & IASLC \\
\hline $40(49)$ & English & USA & LC & 2018 & Testing & J Clin Oncol & CAP; IASLC;AMP \\
\hline $41(50)$ & English & Global & LC & 2018 & Testing & Arch Pathol Lab Med & CAP; IASLC; AMP \\
\hline $42(51)$ & English & USA & LC & 2018 & Screening & J Am Coll Radiol & ACR \\
\hline $43(52)$ & Chinese & China & LC & 2018 & Screening & $\begin{array}{l}\text { Chinese Journal of } \\
\text { Lung Cancer }\end{array}$ & CLCEDTEG \\
\hline $44(53)$ & English & USA & LC & 2020 & Screening & NCCN website & NCCN \\
\hline $45(54)$ & English & USA & LC & 2020 & Screening & J Am Coll Radiol & CHEST \\
\hline $46(55)$ & English & Europe & LC & 2020 & Screening & Cancers (Basel) & IELS \\
\hline $47(56)$ & English & $\begin{array}{l}\text { Southern } \\
\text { Africa }\end{array}$ & LC & 2019 & Screening & $J$ Thorac Dis & $\begin{array}{l}\text { Multidisciplinary } \\
\text { group }\end{array}$ \\
\hline $48(57)$ & English & $\begin{array}{l}\text { Saudi } \\
\text { Arabia }\end{array}$ & LC & 2018 & Screening & Ann Thorac Med & LCPSC \\
\hline $49(58)$ & English & USA & LC & 2018 & Screening & Chest & CHEST \\
\hline
\end{tabular}

ACR, American College of Radiology; AMP, Association for Molecular Pathology; AIOM, Italian Association of Medical Oncology; ASCO, Doctor Association; CHEST, American College of Chest Physicians; CLCEDTEG, China lung cancer early detection and treatment expert group; CMA, Chinese Medical Association; CommNETS/NANETS, Commonwealth Neuroendocrine Tumour Research Collaboration and the North American Neuroendocrine Tumor Society; CSCO, Chinese Society of Clinical Oncology; CSTRO, China Society for Radiation for the Study of Lung Cancer, EELS, Initiative for European Lung Screening; KSMO Korean Society of Medical Oncology: LC, Lssociation regardless of histological type; LCPSC, Lung Cancer Prevention and Screening Committee; NCCN, National Comprehensive Cancer Network; NHC, National Health Commission of the People's Republic of China; NICE, National institute for health and care excellence: NSCLC, non-small-cell lung cancer; OH(CCO), Ontario Health (Cancer Care Ontario); SCLC, small-cell lung cancer; SEOM, Spanish Society of Medical Oncology; SEAP, Spanish Society of Pathology. 